\title{
THE IMPLEMENTATION OF CHILDREN LITERATURE INSTRUCTION IN ELEMENTARY SCHOOL
}

\author{
Muh. Arafik \\ Faculty of Education, State University of Malang, Indonesia \\ arafikmuh@gmail.com
}

\begin{abstract}
Abtract: This study aims at obtaining comprehensive description of the implementation of children literature instruction in Penanggungan Elementary School in Malang. It employs qualitative approach. Instruments used to gather data are interview, participatory observation, and documentation study. Data are analyzed using descriptive qualitative technique. The finding of this study shows that the aim of children literature instruction in Penanggungan Elementary School is to generate students mastering four literacy skills which are: (1) high comprehension reading skill, (2) decent writing skill, (3) fluent and effective communication skills, and (4) skills of handling various types of digital media. Strategies employed to implement children literature instruction are: (1) conditioning friendly-literacy physical condition, (2) creating social and affective environment as literate interaction and communication model, and (3) creating schools as literate academic environment. Children literature instruction is conducting by requiring students to read for 15 minutes at the beginning of lesson. Techniques used are reading aloud, guided reading, group reading, comprehension reading and writing workshop.
\end{abstract}

Keywords: implementation, literacy, children literature

\section{INTRODUCTION}

One of government priorities of development in educational sector is the implementation of 12 year compulsory education. Based on the national law No 20 of 2003 on National Education System, it is stated that all children aging from 7-15 are required to join primary education. It is also inline with target of Smart Indonesian Program which will be achieved by improving quality of educational service, providing excellent operational curriculum and implementing comprehensive assessment system. More specifically, to improve the curriculum, strategy and policy used by government is through improving quality of literacy, math and science instruction. They are considered crucial as basic skills for students to master in order to live their daily live.

In this global era, literacy skill plays crucial role. It is an integral part of education. Literacy functions as means for students to know, understand, and implement what they learn at school. High literacy skill might drive the development of science and technology to a better level. They will be learned better provided that students' mastery of literacy is adequate (Saomah, 2010).

Unfortunately, our success to reduce the number of illiteracy is not supported by improvement of reading habit program at Elementary School. Data of 2014 from UNDP shows that literacy level of Indonesian is $92,8 \%$ for adult and $98.8 \%$ for teenagers. Actually, it shows that Indonesia has passed through emergency stage of literacy problem. However, there has been no literacy stage focusing on skills to make use of information in order to identify, determine, find out, evaluate and create something effectively, to make use and communicate information to tackle various types of problem. However, literacy itself is not adequate to handle global condition of our society.

From international context point of view, as publised in Progress In International Reading Literacy Study, International Association for the Evaluation of Educational Achievement has evaluated reading comprehension of elementary school students every five year since 2001. The aim of literacy test is to asses students' ability to comprehend, make use, and reflect the result of their reading in the form of writing. PIRLS result of 2011 (International Result in Reading), shows that Indonesia is in $45^{\text {th }}$ from $48^{\text {th }}$ countries and its average score is 428 from average score of 500 (IEA, 2012).

The low level of reading interest among Indonesian student is one of of the cause of our inabilty to keep up with global development especially in terms of technology and information. Data from UNESCO (2012) on Indonesian Reading Habit shows that only 1 from 1000 people of Indonesia has good reading habit. It should raise special concern because reading skill is basic requirement to master knowldge, skill and charakter building on the part of students. Low reading habit of Indonesian people is also caused by lack of books. It is apparent from what is stated by resource person in Mata Najwa program broadcasted on Wednesday of June $7^{\text {th }}, 2017$ with "Spreading reading virus".

One of the government efforts to improve students' reading interesst is by releasing School Literacy Movement (SLM). It is developed to realize nine priority agenda (Nawacita) which is related to function and responsibility of Ministry of Education. The point of Nawacita is to improve life quality of Indonesian People; to improve productivity and competitiveness internationally so that Indonesia might rise and develop together with other Asia countries; to transform people's character; to strenghen diversity and social restoration of Indonesia.

The four points of Nawacita is closely related to literacy component as a starting point to realize Indonesian human resources who are qualified, productive, competitive, have positive character and nationalist. To develop Nawacita, there is a need to develop strategy to implement literacy at school in order that it gives positive and sistemic effect. Therefore, schools should: (1) develop themselves into organizations aiming at developing their resources to be individual learner, (2) need to have a leadership 
structure which is integrated with higher structure and adequate resources such as human resources, financial resources and infrastructures; and (3) give educational service in the form of classrooom instruction and other various outdoor activities to support instruction andthe achievement of educational goal (Ministry of Education, 2016).

Concerning the significance of literacy, government should provide and facilitate system and educational service. It is inline with requirement stated in National Law of 1945 Chapter 31, verse 3 "government conduct a system of national education in order to educate Indonesian People and it is formulated further in regulation". This verse requires that literacy program should develop people's potential covering intelectual, emotional, language, aesthetic, social, and spiritual intelligent in order to be able to adapt themselves to development of information technology.

Concerning literacy program, Government enforces Regulation of Education and Culture Minister no 23 of 2015 on Character Building. It requires schools to provide 15 minutes before lesson for students to read. The aim of that activity is to develop student's interest and habit in reading and it is expected to give fun and challenging learning activities for students. By considering characteristic, statement of vision and mission, it will be easier for school as an organization to identify pre determined target and conduct whole school approach for the implementation of program. Good literacy skill is able to improve students' self-concept which in turn to motivate them to have life-long learning. Good reading habit and continuous engagement with reading activities will turn students into life-long learner. Developing students interest in reading, which then turns into reading habit might be started by exposing them to children literatures.

The use of children literature in School Literacy Program is inline with principle of literary activities at elementary schools. Ministry of Education and Culture (2016: 8) stated that meaningful literacy program might be conducted by using reading text containing various types of text such as literature for children and teenager. The next principle is that the book should not be subject-specific text boook. Each individual should have literacy skill to be able to participate in information era and it is part of basic right related to life long learning. Regarding literature, literacy means skill to read and write about literature (Swastika, 2015). Essentially, literature reading is skill to read literature text. Furthermore, literature writing is skill to produce literature text. It also applies to children literature review.

Literacy of children literature might also means ability to identify, determine, find out, evaluate and crate something effectively; to use and communicate children literature object to tackle down various problems. Children literature which is story reading text for children is a kind of litetature written for children. Just like other literary works, children literature texts are product of imaginary factual creation process which are fun and might be able to describe imaginary world, encourage understanding and experience on certain aspect of beauty (Abidin, 2012).

Implementation of children literature in elementary school is targetted on process of delivering literary experience on the part of students. Students are exposed to know forms and contents of children literature. The aim of learning experience to know and be familiar with children literature is to develop appreciation toward literature as beatiful and meaningfull works. Basicaly, the implementation of children literature in elementary school is a process to create an environment to develop students passion toward. This environment system consists of interrelated components. Those are: (1) target that will be achieved, (2) literature text, (3) teacher and students with their own role binding in certain social relation; (4) types of learning activities; (5) available infrastructures; and (6) evaluation. Those componennts are related one to another.

Concerning problems of literacy in elementary school, it is crucial to conduct comprehensive review on implementation of children literature instruction. It should refer to National Program of School Literacy Movement. This qualitative study on implementation of children literature instruction in Elementay school will focus several phenomena related to strategies used, the aims tobe achieved, types of learning activities, the choice of learning resources, surrounding contribution, monitoring and evaluation, problems and solution in implementing children literature in elementary school.

\section{METHODS}

This is qualitative study. It aims at finding out and understanding central phenomenon. The phenomenon tobe found is the implementation of children literature in Elementary School. Qualitative approach is employed due to its ability to describe and understand meaning underlying the behavior of participant, to describe complex bacground and interaction, and to identify types of information as well as to describe certain phenomon.

Data resources on this study can be devided into two which are human and non human. Human as source of data functions as subject or key informant and data gathered through informant is soft data. Non human data source is relevant documents with the focus of study such as certain activities related to the study. The informant chosen are principal, teachers, students, administration staff, librarian, school committee and partners. Sample are taken using purposive sampling technique by selecting and choosing competent informant who have first hand knowledge on the information and who are reliable to be data source. Location of this study is Penanggungan Elementary School in Malang. Data source in the form of documents are written record, voice record, pictures and other objects which is related to the implementation of children literature instruction in elementary school. All finding taken from data are then matched to compose conceptual framework which are then developed into finding abstraction on the field.

Data are collected using interview, questionaire, observation and document study (Bogdan 
and Biklen, 2004). Questionaire and interview is used to obtain information from informant, who are principal, teachers, students, administration staff, librarian and school committee. Observation is conducted to obtain information on the implementation of children literature in elementary school. In this context, observations are conducted to stakeholders at school environment, and classroom environment. Implementation stages of children literature are also observed, monitored and evaluated. Documents, papers, photoes and other documents which are relevant as "resource" are also used to answer questions from researcher. Those documents are school programs, school profile, curricullum, school working program, school history, statements of vision and mission, progress of students' learning. Those documents are related to the implementation of children literatur instruction in Elementary School.

Technique of data analysis used is dscriptive technique. The steps are: (1) reducing data, by classifiying, directing, sorting out unimportant data and organizingd ata; (2) presentingd ata by finding out relation pattern which is meaningfull and raise possibility to draw conclusion; and (3) drawing conclusion and verification (Miles and Huberman, 1994).

\section{RESULTS AND DISCUSSION 1. The Purpose of Children Literature Instruction}

Entering $21^{\text {th }}$ centiry, the main objective of literature instruction is to provide opportunities for students to develop their potentials as competent communicator in multicontext, multiculture and multimedia environment by empowering their multiintelligence. In line with context of study, the objective of children literature instruction in Penanggungan Elementary School is to generate students mastering four skills. Those skills are: (1) high reading comprehension, (2) decent writing skills, (3) fluent and effective commuunication skills, and (4) skills of handling various types of digital media.

The purpose of children literature instruction in Penanggungan Elementary School in Malang is inline with the main goal of literacy instruction in $21^{\text {st }}$ century. The goals are: (1) to encourage students to be reader, writer and strategic communicator, (2) to improve students' thingking skill and to develop students' thinking habit, (3) to improve and strengthen students' motivation to learn, and (4) to develop students' independency as a creative, inovative, and productive learners (The Ontario Ministry of Education, 2006).

Concerning the goal of literacy instruction, we need to review statements from Morocco et al (2008) on competence that should be able to master in $21^{\text {st }}$ century. For them, the purpose of instruction in $21^{\text {st }}$ century is to develop four foundations of $21^{\text {st }}$ competence. They are high understanding on concept, critical thinking skill, skill to commnicate and collaborate with others and creative thingking skills.

In order to develop schools as learning organization, Ministry of Education and Culture declares School Literacy Program (SLM). It is an thorough effort involving all stakeholders (teachers, students, parents) and people as part of educational ecosystem. Based on the context of SLM, the definition of school literacy is development of skill to access, understand and make use of available resourcess through various kinds of activities such as reading, observing, listening and/or speaking.

Specific objective of SLM is to develop students' characters through empowerment of "school literacy ecosystem in the form of children literature instruction to transform students into long life learner". General objective of SLM is to develop literacy culture at school, and to improve school stakeholders' capacity and environment to be more literate, as well as to transform school into fun and friendly learning place. The last general objective is to sustain learning process by presenting various kinds of children literature text and apllying reading strategies.

\section{Strategy of Children Literature Instruction}

There are many strategies used to implement children literature instruction in Penanggungan Elementary School. They range from general until specific strategy. At school level, principal formulates clear, measurable and continuous policy on children literature instruction program. School also promotes literacy program of children literature contunously, gives clear information on the significance of children literacy program for all stakeholder. Furthermore, school also provide rewards for those showing achievement in literacy. One of the reward is selection of literacy ambassadors. They are chosen based on several pre determined criteria. Then, literacy ambassadors are required to support other students to encorage their interest in reading.

There is also special strategies to implement literacy of children literature in Penanggungan Elementary School. Creating friendly physical condition for literacy program is crucial part to support the general strategies stated above. It is due to that physical environment is the first to see and feel by people. Physical environment should be friendly and supportive for learning. Students' works which are related to literacy program should be exposed at school area such as classroom, school garden and library. Those works are continuously replaced by other works. Other strategy to create friendly-literacy physical environment is to set up reading corner. Students might access reading materials at reading corners not only at library. Classroom filled with students works will raise positive image on schools' commitment to development of literacy culture.

At school level, the success of SLM is influenced by support from regional government in socializing the program, increasing role and capacity of stakeholders (principal, teacher, administration staff, and school committee). This increasing capacity might be realized through training. Furthermore, the continuity of SLM program is also influenced by the availability of infrastructures supporting SLM. In order to make school to be a pioneer in literacy culture, Beers, et al (2009) provides several strategies to create 
positive literacy culture. Those strategies are: (1) conditioning friendly-literacy physical condition, (2) creating social and affective environment as literate interaction and communication model, and (3) creating schools as literate academic environment.

\section{Instructional Activities for children Literature}

Ministry of Education and Culture (2016) stated that SLM program will be conducted gradually considering schools' readiness and commitment. It includes school capacity (available facilities, reading materials, and infrastructure for literacy), readiness of stakeholder and other supporting system (public participation, institutional support and relevant policy). SLM is devided into three stages which are conditioning stages, instructional stages and development stage.

Instructional activities of children literature at Penanggungan Elementary School is in conditioning stage in which students are required to read for 15 minutes before lesson. SLM strengthens characters building as stated in Regulation of minister of education and culture no 23 of 2015. The purpose of that activity is to develop students habit of reading and to improve students' reading skill. The reading materials contains moral value, local, national and international wisdom delivered based on students' level of development.

Most commonly activities done during 15 minute reading is reading aloud. The purpose is to motivate students to read, to make students love reading and to provide fund and challenging reading task as well as to build communication between teacher and students in which teacher functions as role model in reading. Interactive read-aloud strategy is able to develop students' skill t predict, make connection and draw conclusion of reading material (Hoyt, 2007). The implementation of children literature instruction on development stage is condcted by guided reading activities. Students are grouped based on their similar level of reading. Students in one group makes use similar reading material. Reading material of one group is different with that of others. Teacher give guidance for each group based on the need of each group which is related to their reading comprehension skill, their fluency in reading, their vocabulary and their awareness on word sound. This guided reading activities are integrated into independent reading activities.

In addition to guided reading, teacher also conducts reading comprehension activity. The purpose is to construct meaning. If students read words that they don't understand, the students are not reading (NRP, 2004). To construct meaning, reader should be able to relate what they read with what they know on the topic (Sweet \& Snow, 2003). During the processs, students need basic skills to be able to read fluently using various kind of strategy.in short students should understand what they hear and what they read. Good readers are those having objective in reading. They know why they read. They think and are actively involved during reading. Comprehension is complex process. Good reader makes use their knowledge on vocabularies, sentence structures and reading strategies. They understand text, they are able to anticipate problems in reading and they know how to comprehend what they read (Armbruster et al, 2001).

Literacy activities on instructional stage aims at debveloping skill to understand the text and make relation with their personal experience, encouraging critical thinking and sharpening communication skill by responding to enrichment reading text and textbooks (cf Anderson \& Krathwol, 2001). On this stage, there is an academic claim. Reading activities on this stage is to support the implementation of 2013 curricullum in which students are required to read books on general knowledge, hobbies and interest, or multimodal text. At least, students of elementary schools should read six books. Literacy activities on instructional stage is aiming at improing receptive and active language skill which are elaborated in reading and writing. Reading and writing are graded to facilitate the assesment of students' mastery on the four area of language (reading, listening, speaking and writing). Levels of skill in reading and writing are novice, beginner and intermediate.

On instructional stage, activities conducted are not only applying multiple reading strategies but also setting up writing workshop. It is a writing instruction by applying preparatory stage, composing text draft, revising, editing and publishing. Writing Workshop is a student-staffed program designed to provide assistance at any stage of the writing process, from initial brainstorming to final drafts (Williams College, 2014).

\section{CONCLUSION}

Individuals should master literacy skill to be able to take part information community and it is also basic right related to life long learning. Literacy program of literature is skill to read and write lirerary work. Children literature instruction in this study is skill to read and write on children literature. As part of literary skill, skill of reading and writing literature should be taken into account. It is not only part of instruction but it is expected that children literature instruction will be able to encourage students to develop their potentials in appreciating literature. There are many activities that can be used to create fun and challenging instruction for literature by using various learning resources.

Literature might give positive effect and contribution for students; thus children literature instruction should be implemented at elementary school. It is done by consideringthe benefit and character of each school. At least, school should have reading and writing activities for literature and it is not only part of instruction but also functions to develop students' potentials in literature as part of literature appreciation itself.

\section{REFERENCES}

[1] Almerico, G. M. 2014. Building Character Through Literacy with Children's Literature. Research in Higher Education Journal, 26, 1-10. 
[2] Anderson, L. W., \& Krathwohl, D. R. 2002. A Taxonomy for Learning, Teaching, and Assessing. A Revision of Bloom's Taxonomy of Educational Objectives. New York: Longman.

[3] Armbruster, B. B., Lehr, F., \& Osborn, J. 2001. Put Reading First: The Research Building Blocks for Teaching Children to Read. Washington, D.C.: National Institute for Literacy.

[4] Beers, C. S., Beers, J. W., \& Smith, J. O. 2009. A Principal's Guide to Literacy Instruction. New York: Guilford Press.

[5] Bjorklund, D. F. 2005. Children's Thinking. Cognitive Development and Individual Differences. Belmont: CA: Thomson Wadsworth Learning.

[6] Brady, L. 1991. Children and Their Books: The Right Book for the Right Child 1. Melbourene: The Macmillan Company.

[7] Bogdan, R.C., \& Biklen, S. K. 1992. Qualitative Research for Education: An Introduction of Theory and Methods. Boston: Allyn and Bacon.

[8] Cambridge Assesssment. 2013. What is Literacy? An Investigation into Definitions of English as Subject and the Relationship between English, Literacy and being Literate: A Research Report. London: Cambridge Assesssment.

[9] Direktorat Pembinaan Sekolah Dasar. 2011. Panduan Pembinaan Pendidikan Karakter melalui Pengembangan Budaya Sekolah di Sekolah Dasar. Jakarta: Direktorat Pembinaan Sekolah Dasar Direktur
Jenderal Pendidikan Dasar Kementerian Pendidikan dan Kebudayaan.

[10] Goetz, J. P., \& LleComte, M. D. 1984. Ethnography and Qualitative Design in Education. San Diego: Academic Press, Inc, Harcourt Brace Jovanovich.

[11] Haiyan, Z. (2008). Values and limitations of children's literature in adult language education. US-China Foregin Language, Mar 2008, Volume 6, No.3 (Serial No.54).

[12] Hoggart, R. 1998. Critical Literacy and Critical Reading. In Cox B. (Ed) Literacy Is not Enough: Essays on the Importance of Reading. Manchester: Manchester University Press.

[13] Huck, C. 1987. Children's Literature in the Elementary School. New York: Holt, Rinehart and Winston.

[14] Hunt, P. 1995. Criticism, Theory, and Children's Literature. Cambridge, Massachusetts: Blacwell.

[15] Kemendikbud. 2016. Desain Induk Gerakan Literasi Sekolah. Jakarta: Ditjen Dikdasmen.

[16] Kemendikbud. 2016. Panduan Gerakan Literasi Sekolah di SD. Jakarta: Ditjen Dikdasmen.

[17] Kemendikbud. 2016. Buku Saku Gerakan Literasi Sekolah. Jakarta: Ditjen Dikdasmen.

[18] Kern, R. 2000. Literacy and Language Teaching. Oxford: Oxford University Press.

[19] Manolistis, G., Georgiou, G. K., Parilla, R. 2010. Revisiting the Home Literacy Model of Reading Development in an Orthographically Consistent Language,

21 , 496-50. 